\title{
LASER DOPPLER FLUXMETRY
}

\author{
Stanislav Sarnik ${ }^{\mathrm{a} *}$, Ivo Hofirek ${ }^{\mathrm{a}}$, Ondrej Sochor ${ }^{\mathrm{a}}$ \\ ${ }^{a}{ }^{\text {st }}$ Department of Internal Medicine - Cardioangiology, St. Anne's University Hospital Brno \\ *e-mail: stanislav.sarnik@fnusa.cz
}

Received: April 30, 2007; Accepted (with revision): June 1, 2007

Key words: Laser Doppler fluxmetry/Periflux 5000/Tissue blood supply/Peripheral microcirculation

Background: Laser Doppler fluxmetry (LDF) is an extraordinary sensitive noninvasive method of examination. It can be used for monitoring changes in the cutaneous peripheral microcirculation ${ }^{15}$. It uses a monochromatic low-energy laser beam. This beam penetrates the tissue and, depending on individual tissue penetration, it is reflected, recorded by a sensitive sensor and subsequently analyzed using the Doppler. Laser Doppler fluxmetry detects movement of cells in the peripheral circulation and microcirculation.

Methods: The light from the laser source is delivered via optical fibers to the tissue. In the tissue the light collides with moving blood elements; after a collision, the wave length of the light changes - this phenomenon is called Doppler shift. Our own method of measurement has already been fully developed. We have a group of patients with physiological findings and also groups of patients with vasoneurosis, patients with type 1 diabetes mellitus, vasculitis patients, and other patient groups. We examine the blood flow on the dorsal side of fingers or toes. There are many protocols for laser Doppler examination. For all the patient groups we used a protocol evaluating an algorithm, developed in the training department of the Perimed company, using provocation tests for the assessment of the vascular wall function in addition to records at rest.

Use of laser Doppler: We have developed a method of use of laser Doppler examination in about 8 years. We have examined several groups of patients. First a patient group with physiological findings was examined, and subsequently groups of patients with vasculitis, vasoneurosis, and a group of patients with type 1 diabetes mellitus. Recently, monitoring has been performed in patients after cardioversion in chronic atrial fibrillation with sinus rhythm restitution, and also data obtained before and after a varicose vein operation on lower limbs have been compared.

Conclusion: Clear diagnostic criteria for this method do not exist so far. For the time being this is a rather theoretical method that we used even in practice for the above mentioned diseases. The method provides enough data even for more detailed analyses. The information valu of the curve arises after statistical data analysis with the t-test.

\section{INTRODUCTION}

Laser Doppler fluxmetry (LDF) is an extraordinary sensitive noninvasive method of examination. It can be used for monitoring changes in the cutaneous peripheral microcirculation ${ }^{12}$. It uses a monochromatic low-energy laser beam. This beam penetrates the tissue and, depending on individual tissue penetration, it is reflected, recorded by a sensitive sensor and subsequently analyzed using the Doppler effect ${ }^{1}$, (Fig. 1 - laser beam penetration through the tissue, reflection and analysis in the amplifier). Laser Doppler fluxmetry detects the movement of cells in the peripheral circulation and microcirculation, i.e. in arterioles, venules, and capillaries with a cross-sectional area of $0.002 \mathrm{~mm}^{2}-0.008 \mathrm{~mm}^{2}$ (ref., ${ }^{4}$ ). In this way cells are detected (especially erythrocytes, sporadically leucocytes) moving at a velocity of $0.01-10 \mathrm{~mm} / \mathrm{s}$. LDF records the cellular movement of erythrocytes mainly in ascendent arterioles. Basic depth penetration of laser Doppler fluxmetry is about $1.5 \mathrm{~mm}$.

The cutaneous microcirculation is organized in two horizontal plexuses: a superficial one situated approxi- mately 1.0-1.5 mm under the skin surface and a deeper one in the area of the cutis and subcutis connection.

Ascendent arterioles and descendent venules ramify in both plexuses ${ }^{12}$.

In addition to the total flow intensity and intensity of individual pulse waves, LDF can record rhythmical changes in the cutaneous microcirculation blood flow, the so-called spontaneous vascular movements ${ }^{12}$ (vasomotion), (Fig. 2.).

In our department we use the PERIFLUX 5000 measurement system (Fig 3)(ref. ${ }^{5}$ ). The device consists of a measurement unit with a probe and a computer where recording and subsequent evaluations are performed.

PeriFlux 5000 is a multichannel laser-Doppler system which is one of the most sophisticated systems currently available.

A large number of probes can be connected to the PERIFLUX 5000 system which can be used in various clinical fields 5 :

- Angiology, cardiology, and vascular surgery

- Dermatology

- Diabetology

- Pharmacology 
- Neurosurgery

- Plastic surgery, burns

- Transplantations and many other fields

\section{Theory and principle of the method ${ }^{13}$}

Blood supply (perfusion) of a tissue is measured in so-called PU (Perfusion Units). As tissue blood supply (perfusion) cannot be expressed in absolute physical units (e.g. as $\mathrm{ml} / \mathrm{min} / 100 \mathrm{~g}$ of tissue), $\mathrm{PU}$ is a dimensionless quantity ${ }^{6}$.

The light from the laser source is delivered via optical fibers to the tissue. In the tissue the light collides with moving blood elements; after a collision, the wave length of the light changes - this phenomenon is called Doppler shift. Changes in wave length and light intensity amplitude are proportional to the number and velocity of moving blood elements, i.e. tissue blood supply (perfusion):

Tissue blood supply (perfusion) $=\mathbf{n}_{\mathrm{ke}} \mathbf{X} \mathbf{v}_{\mathrm{ke}}$ $\mathrm{n}_{\mathrm{ke}}$ is the number of moving blood elements in the measured volume

$\mathrm{v}_{\mathrm{ke}}$ is the mean velocity of blood elements in the measured volume

The depth of measurement depends on three factors:

- Tissue characteristics

- Probe configuration

- Wave length

\section{Methods of measurement}

Our own method of measurement has already been fully developed. We have a group of patients with physiological findings and also groups of patients with vasoneurosis, patients with type 1 diabetes mellitus, vasculitis patients, and other patient groups ${ }^{12}$. We examine the blood flow on the dorsal side of fingers or toes. In this way, the area of both superficial and deep vascular plexuses is recorded. The measurement is influenced by a variety of factors: wave length of the beam, temperature of the object, systemic blood pressure, milieu interieur (especially oxygen saturation), drug therapy, alcohol abuse, smoking. On the day of examination the patients are not allowed to smoke or to drink alcohol ${ }^{13}$.

There are many protocols for laser Doppler examination. For all the patient groups we used a protocol evaluating an algorithm, developed in the training department of the Perimed company, using provocation tests for the assessment of the vascular wall function in addition to records at rest ${ }^{3,13}$ :

1. Systemic blood pressure measurement on the patient's arm, taking down the results

2. Putting a scanning probe on the patient's limb (on the first or second toe, middle of the second phalang, on skin apart from visible vessels, or alternatively on the second or third finger, likewise in the middle of the second phalang. After obtaining the best quality of record, the recording is started.

3. A 10-min record at rest

4. A 4-min ischemization of the limb (systolic blood pressure $+50 \mathrm{~mm} \mathrm{Hg}$, max. $240 \mathrm{~mm} \mathrm{Hg}$ ).

5. After cuff deflation, a 15-min record at rest

6. $2 \times$ sublingual administration of Nitromint spray $(2 \times$ $0.4 \mathrm{mg}$ ) or another nitrate spray

7. a 10-min record

\section{Evaluation rules}

It was necessary to unify the rules for evaluation of the records (Fig. 5)

1. Resting period: evaluation of last 4 min (area 1)

2. Postocclusive reactive hyperemia: first 4 min (area 2) and last 4 min (area 3)

3. Nitromint test analysis: first $5 \mathrm{~min}$ (area 4)

The resulting curve of a time period of approximately 45 minutes shows plus and minus oscillations from zero, depending on the movement of blood elements and spontaneous vascular movements in the measured and scanned area. Then the resulting data can be processed and used for various comparisons. Slow cyclic changes in the intensity of the peripheral circulation response are considered to be manifestations of possible spontaneous vascular movements ${ }^{15}$ (vasomotion). In frequency analy-

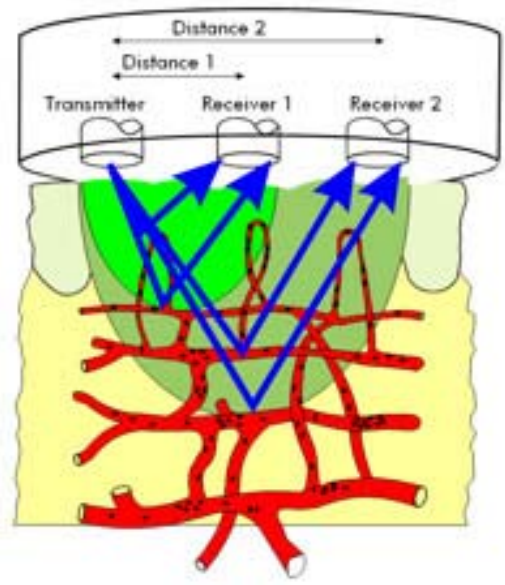

Fig. 1. (ref. $^{5,6}$ )

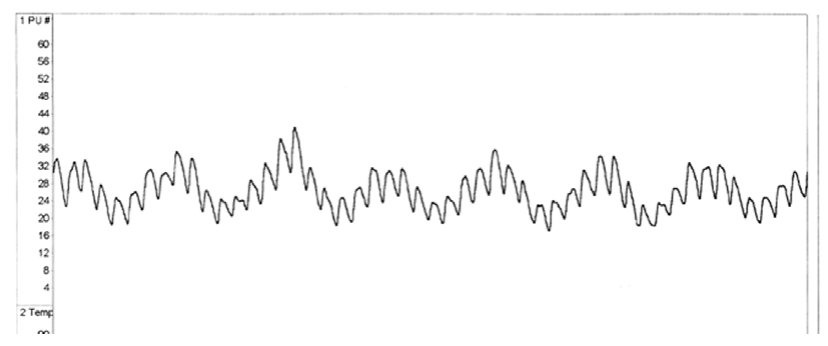

Fig. 2. (ref. ${ }^{5,6}$ ) 
ses, intensity of vascular movements was evaluated in the frequency range of $0,008-0,200 \mathrm{~Hz}$ (this is the so-called slow vasomotion - SV, circa 0,5-12/ $\mathrm{min}$ ) and in the range of $0,210-0,420 \mathrm{~Hz}$ (fast vasomotion - FV, circa 12-25 / min) (15). Intensity of vascular movements (vasomotion) in PU units was compared at various frequencies of the measured $\mathrm{SV}$ and FV segments in steps of $0,007 \mathrm{~Hz}$ according to the our evaluation protocol as compared to a commercially offered evaluation in steps of $0,1 \mathrm{~Hz}$. Thus approximately seven times more data can be processed from individual measurements. (Fig. 4)

The measurement unprocessed data are extracted directly from the source software, transferred to a text file and subsequently analyzed in a spreadsheet. Each patient examined had 75 monitored frequencies in two channels, altogether more than 170 monitored parameters. Most frequently, the t-test was used for statistical analysis ${ }^{3,13}$.

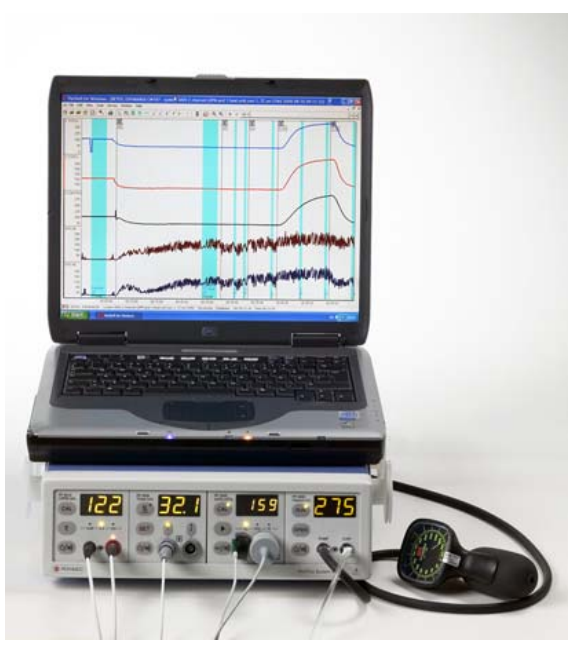

Fig. 3. (ref. ${ }^{5,6}$ )

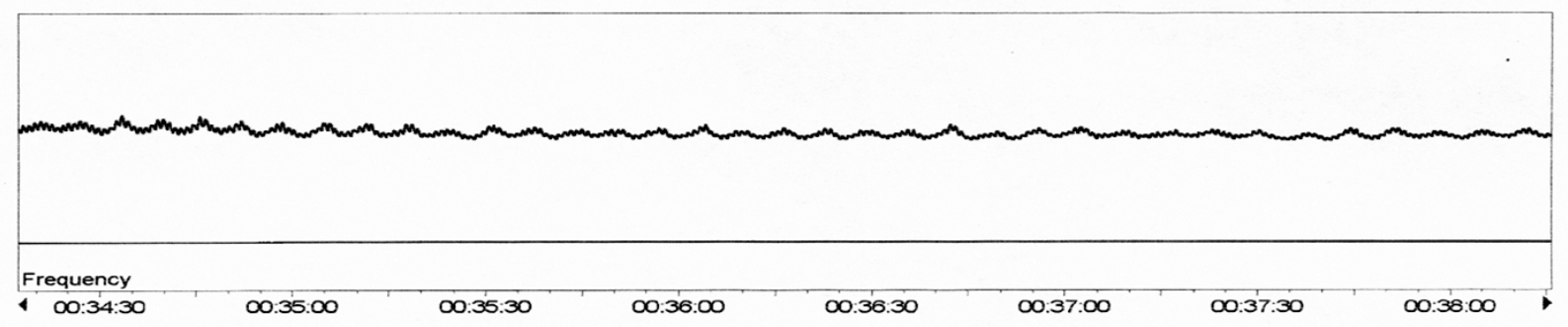

\section{Calculations}

\begin{tabular}{|lr|r|r|}
\hline \multicolumn{1}{|c|}{ Item } & & \multicolumn{1}{|c|}{ Chan 1 } & \multicolumn{1}{c|}{ Chan 2 } \\
\hline Mean value & (Unit) & 28,4 & 34,4 \\
Maximum value & (Unit) & 54,6 & 34,5 \\
Minumum value & (Unit) & 15,7 & 34,2 \\
Area under curve & (Unit"sec.) & 6775 & 8210 \\
Duration & (sec.) & 239 & 239 \\
Relative start time & (hh:mm:ss,fr) & $00: 34: 17$ & $00: 34: 17$ \\
Relative stop time & (hh:mm:ss,fr) & $00: 38: 16$ & $00: 38: 16$ \\
\hline
\end{tabular}

Channel 1 : PU \#1
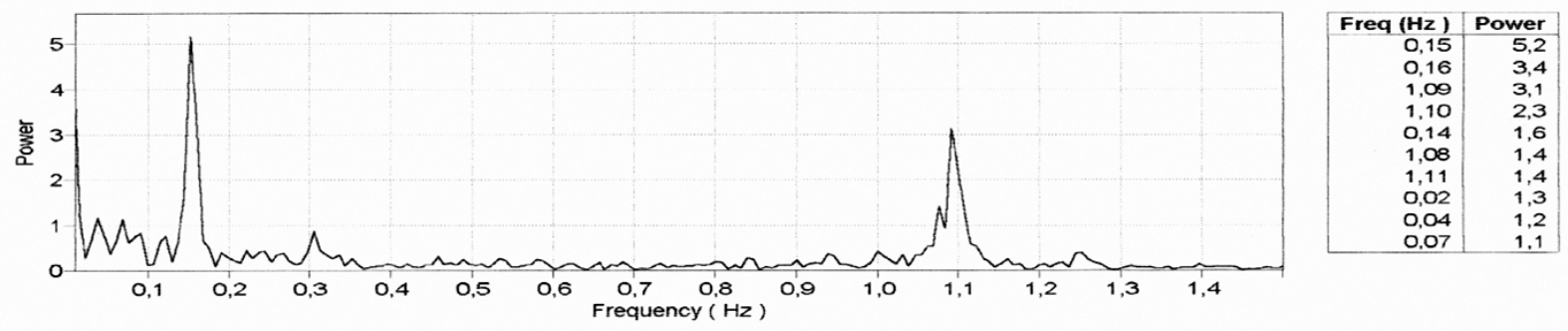

Fig. 4. (ref. ${ }^{5,6}$ )

Area 1

Area 2

Area 3

Area 4

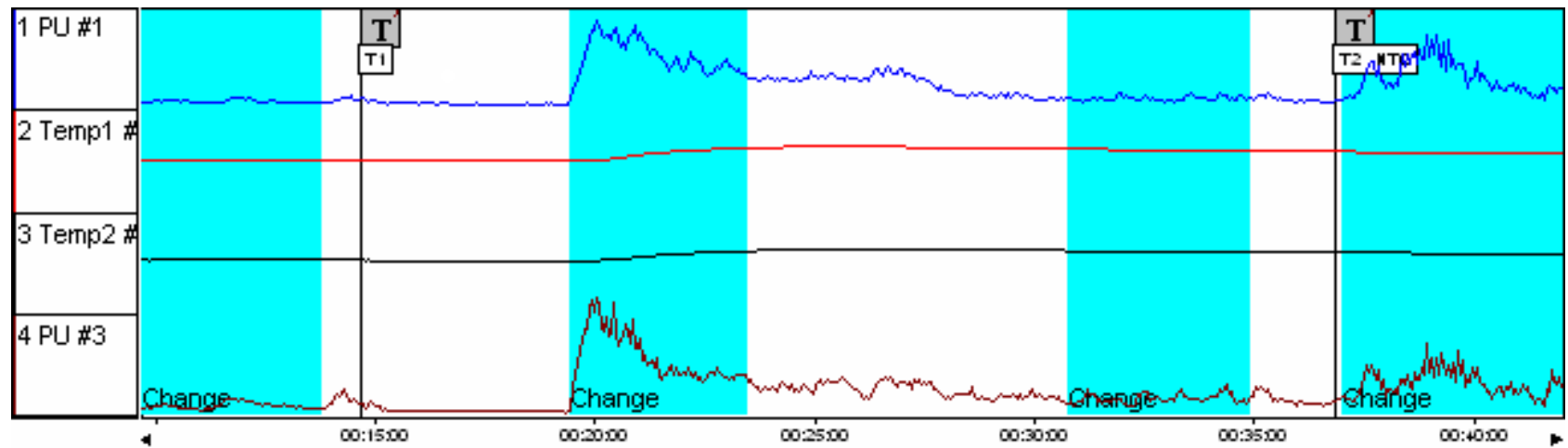

Fig. 5. 


\section{Use of laser Doppler fluxmetry}

At our department, we have developed a method of using laser Doppler examination over about 8 years ${ }^{12}$. We have examined several groups of patients. First a patient group with physiological findings was examined, and subsequently groups of patients with vasculitis, vasoneurosis, and a group of patients with type 1 diabetes mellitus. Recently, monitoring has been performed in patients after cardioversion in chronic atrial fibrillation with sinus rhythm restitution, and also data obtained before and after a varicose vein operation on lower limbs have been compared. We also attempted to carry out experimental studies dealing with the impact of smoking on the peripheral microcirculation ${ }^{14,17}$. We have also published papers dealing with changes in the peripheral microcirculation during extracorporeal circulation ${ }^{15}$. Our first results of drug effect testing are promising as well ${ }^{16}$.

\section{CONCLUSION}

The paper describes original data on the method and examination of peripheral circulation with laser Doppler fluxmetry. The experience with this method is described in rather general terms. Clear diagnostic criteria for this method do not exist so far. For the time being this is a rather theoretical method that we used even in practice for the above mentioned diseases. The method provides enough data even for more detailed analyses. The information value of the curve arises after statistical data analysis with the t-test. We have not determined both specifity and sensitivity of the method yet, and these are not clearly specified in the literature.

\section{REFERENCES}

1. Mayrovitz H.N.- Groseclose E.E.: Inspiration-induced vascular responses in finger dorsum skin. Microvascular Research 2002; 3:23-26.
2. Crandall C G, Shibasaki M, Yen T C. Evidence that the human cutaneous venoarteriolar response is not mediated by adrenergic mechanism. Journal of Physiology 2002; 1:36-39.

3. Hofírek I. Vasculitidy, vasculopatie. Kardiologická revue; Brno 3, p. 11-13

4. Prázný M. Examination of tissue perfusion by laser doppler flowmetry. Diabetes, metabolismus, endokrinologie 2000; 2:30-33.

5. www.medata.cz. Evaluations

6. www.perimed.se

7. Microcirculatory stasis, at the root of venous disease, Phlebo-lymphology, No.5, European Conference on Microcirculation; 1994, Rome, p. 36-38

8. Bornmyr S, Arner M, Svensson H. "Laser Doppler imaging of finger skin blood flow in patients after microvascular repair of the ulnar artery at the wrist" Journal of Hand Surgery 1994; 19B(3):295-300.

9. Bornmyr S, Svensson H, Söderström T, Sundkvist G, Wollmer P. "Finger skin blood flow in response to indirect cooling in normal subjects and in patients before and after sympathectomy" Clinical Physiology 1998; 18(2): 103-107.

10. Ferrell W R, Sturrock R D, Mallik A K, Abbot N C, Lockhart J C, Edmondson W D. "Laser Doppler perfusion imaging of proximal interphalangeal joints in patients with rheumatoid arthritis" Clinical and Experimental Rheumatology 1996; 14:649-652.

11. Picart C, Carpentier P H, Brasseur S, Galliard H, Piau J.M. "Systemic sclerosis: Blood rheometry and laser Doppler imaging of digital cutaneous microcirculation during local cold exposure" Clinical Hemorheology and Microcirculation 1998; 18:47-58.

12. Hofírek I, Sochor O, Olšovský J. Změny periferní mikrocirkulace u diabetiků 1. typu sledované laser dopperem. Vnitřní lékařství 2004; 50(11):836-841.

13. Šárník S. Poruchy mikrocirkulace u chronické žilní nedostatečnosti. Kardiologická revue 2005; 7(3):152-155.

14. Sochor O, Hofírek I. How long change cigarette peripheral vasomotion? Praktická flebologie in print

15. Sochor O, Hofírek I, Vitovec J. Peripheral microcirculation during the extracorporal circulatoin using frequency analysis of Laser Doppler Fluxmetry. International Angiology 2006; 25(2), suppl $1: 182$

16. Hofírek I, Sochor O, Šárník S. Vliv diabetu na reaktivitu mikrocirkulace u pacientů s vasospastickým onemocněním a vliv rheologické terapie. CEVJ (Central European Vascular Journal) Feb 2007; 6(1):13

17. Sochor O. Smokers and vascular diseases. What should we do with them? CEVJ (Central European Vascular Journal) Feb 2007; 6(1): 17. 